\title{
高性能アルミナー炭化ケイ素系複合材料の開発
}

\author{
中 平 敦* \\ Atsushi NAKAHIRA
}

\section{1. 研究遂行上感じたこと}

学部時代, 夢の材料としてあらゆる産業分野で脚光 を浴びていたセラミックスに興味を覚えたことがセ ラミックスとかかわる出発点となりました。東北大学 工学部の修士進学当時, 著者は迷う事なくセラミック 又を研究対象として選択し, 種々の特性の中で, 特に 機械的性質をテーマに選びました。ちょうどアメリ カのヴァージニア工大で客員生活を終えて帰国された 新原先生は, 欧米の模倣ではない新規な七ラミックス 材料設計の確立に情熱を注がれており，その情熱に感 銘を覚えた著者は, その研究方針に従ってセラミック スの微細組織を複合化により制御し，七ラミックスの 種々の機械的性質を改善するための基礎研究をス夕一 トしました。

著者は当時新しく開発された高純度で超微粉のアル ミナをマトリックスとして選び, 第2 相として炭化ケ 傃を選択しました。当時(10年ほど前), 使用できる 炭化ケイ素粉末が2〜3種類しか手に入らず苦労したこ とが思い出されます。現在は種々の炭化ケ傃粉末が 市販されており, その後, 炭化ケイ素ウイスカーなど も量産化されるようになり，ますます複合化の幅が大 きく広がりました。本研究で取り上げたアルミナと炭 化ケイ素の取り合わせは, アルミナと炭化ケイ素が反 応しにくいこと, 拡散速度が大きく異なること, 更に 熱膨張係数が大きく異なる(炭化ケイ素の熱膨張係数 はアルミナの約 $1 / 2)$ ので残留応力が利用できること 等, セラミックスの複合化の研究を遂行するためのモ

平成 5 年 9 月 8 日 受付

*大阪大学産業科学研究所

（于567 茨木市美穂ヶ丘 8-1）TEL. 06-877-5111

〈著者紹介〉

昭和57年東北大学工学部金属加工学科卒, 昭和59年東北大学工学部工 学研究科金属材料工学博士課程前期修了, 同年東北大学金属材料研究 所所助手, 昭和 62 年防衛大学校助手, 平成 2 年 研究所助手。工学博士。専門 : 材料科学。

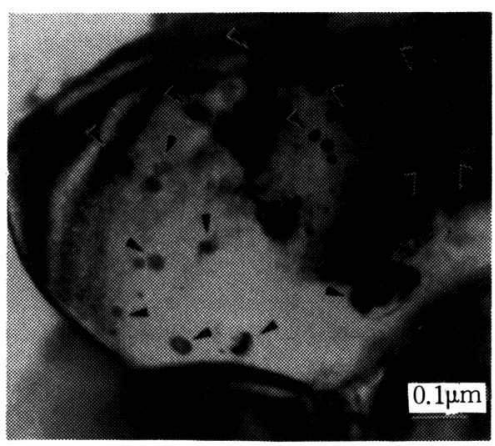

図 1 アルミナー炭化ケイ素系ナノ複合材料のTEM写真

デル材料には最適でした。

七ラミックスを高温構造材料として実用化するとい う明確な目標があるため, 研究は現状の強度, 信頼性, 耐熱衝撃性, 高温特性の大幅な改善を目指しました。 試行錯䛊の予備実験から特性改善を可能にするために 必要な微細組織は, 七ラミックス母相の粒内に第 2 相 を分散させた組織を実現すればよい，ということに気 付いたのが研究を初めて 3 年ほど経過した頃でした。 目指す目標が明確になれば, 研究は急速に進展するも ので, 次の年には種々の製造プロセッシングに改良を 加え, 図 1 に示すように, アルミナ粒内にナノメータ 一サイズの微細な炭化ケイ素粒子が分散した微細組織 を有する,アルミナー炭化ケイ素系ナノ複合材料が得 られました。このように進めてきた研究課程で強く感 じたことは, 得られた成果も確かに重要ながら, 独創 性を絶えず念頭において研究・探求できたのが大きな 成果となった気がします。

\section{2. 主な成果}

アルミナー炭化ケイ素系複合材料について種々の機 械的性質・熱的性質を評価し，また微細組織を透過型 顕微鏡で詳細に観察した結果, ナノ複合化による組織 
制御が，アルミナの機械的性質の向上に非常に有効で あることが明らかとなり, その研究成果を基礎として 高性能なアルミナ基ナノコンポジットの開発に成功 しました。以下にその結果を要約すると,

（1）製造プロセスの最適化により，アルミナの結晶 粒内にナノサイズの炭化ケイ素粒子が分散したナノ複 合材料の焼結法による製造に成功し, 透過型電子顕微 鏡観察等により,ナノ複合化を達成するための条件を 明らかにした。

（2）ナノ複合化によりアルミナの各種の機械的特性 が飛躍的に改善されることを見い出し，図2に示すよ うに, 特に破壊強度は僅か $5 \mathrm{vol} \%$ の炭化ケイ素をナノ 複合化するだけで 4 倍以上(最適な熱処理を施すこと により約 $1500 \mathrm{MPa}$ の高強度)も，破壤勒性は1.5倍以上 も改善されることを明らかにした。

（3）ナノ複合化により,アルミナマトリックスの結 晶粒が粗大化・不均質化しても強度は低下せず，また 破壊強度のバラッキも逆に減少し, 信頼性が向上する ことを見い出した。

（4）本複合系のこれらの特性改善は，アルミナと炭 化ケイ素の熱膨張係数差に起因する残留応力により， アルミナ粒内に転位のネットワークとサブ粒界が形成 され，破壞源寸法が著しく減少するためであることを 明らかにし，七ラミックスの材料分野において転位論 による材料設計を導入することに初めて成功した。

(5) 高温機械的性質の評価から, 炭化ケイ素ナノ粒 子は，スロークラックグロース及び転位移動の抑制に も威力を発揮し, 高温硬度, 高温強度, クリープ変形抵 抗をも著しく改善することを明らかにした。

以上のように, 本研究結果から,ナノメーターレベ ルの複合化によりアルミナの飛躍的な高性能化に成功 すると共に，セラミックスの材料設計に新しいコンセ プトを導入することが可能となった。これらの成果 は, 機械的性質のみならず種々の特性改善にも有効で あり，またアルミナのみならず他の酸化物系七ラミッ クスや非酸化物系セラミックスにも適用可能であり, その後多くの優れた研究成果が得られました。

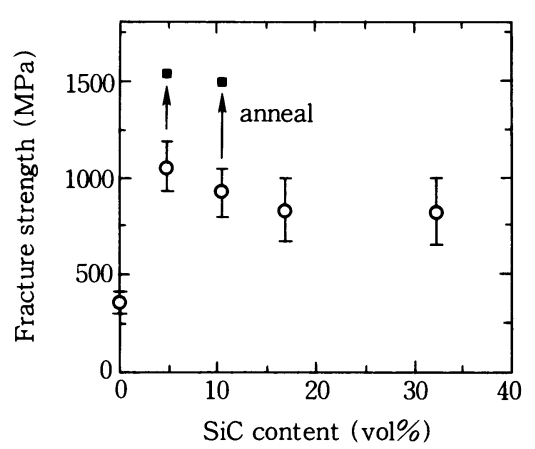

図 2 アルミナー炭化ケイ素系ナノ複合材料の強度

\section{3. 研究を終えて}

本学位論文の主查であり, 直接の指導を賜った大阪 大学産業科学研究所新原晧一教授には, 実験の仕方・進 め方など研究のイロ八から教えて頂いた。さらに現在 の日本の研究者に必要なのは“欧米の研究の模做では ない, 独創性のある研究をすすめることである”と折 りに触れて新原教授からたたき込まれたことが, 学位 の取得以上に有益であったと思われる。さらに, 研究 の進め方以外にも人や学生との接し方についても, 折 りに触れて体験することができたことが有意義でし た。

また, 本研究で取り上げた複合系に早くから注目さ れ, 研究の本質がナノーターレベルの組織制御にある と看破されていた新原教授の先見の眼の確かさや着眼 のノウハウに触れることができたのが, 今後の研究を 進める上で貴重な体験となったと思われます。

学位の取得後, 現在, 本研究で得られたセラミック 又複合材料の特性を更に改善するために, 必要なプロ セッシングの開発について検討しており，またナノ メーターレベルで組織制御するナノ複合化の技術を, 七ラミックス以外の種 々の材料, 例えば金属間化合物 やポリマーに適用することも現在試みている。この ような研究を通して, 今後, 新しい材料設計の指針の開 発を目指して行きたいと考えている。 (学位授与は1993年 2月, 大阪大学) 